\title{
Omkring modelprogrammets tilblivelse og funktion
}

\author{
Jens Thorhauge
}

Modelprogram for folkebiblioteker (http://modelprogrammer.slks.dk/) er en af det danske biblioteksvæsens nyere succeser. Ikke bare er det blevet en dynamisk ramme for deling og udvikling af erfaringer med biblioteksudvikling mellem danske biblioteker, det er også blevet en eksport artikel, både til Norden og den øvrige verden. Programmet bygger på firerumsmodellen, som Dorte Skot-Hansen har været en afgørende person bag. Jeg har været aktiv i promovering af programmet og har i de seneste år noteret mig, at det ofte går under navnet The Danish Model. Programmet er fortsat højt prioriteret i Slots- og Kulturstyrelsen. Som initiativtager og aktivt medvirkende til programmets realisering skal jeg her knytte nogle personlige kommentarer til programmets tilblivelse og baggrund, der dels belyser hvordan programmet blev til og dels giver et bud på, hvorfor det slog så bredt igennem, som tilfældet var og er.

\section{Modelprogrammet og rapporten Folkebiblioteker- ne $i$ vidensamfundet}

Programmet er en udløber af arbejdet med rapporten Folkebibliotekerne $i$ vidensamfundet (Styrelsen for Bibliotek og Medier (2010). Rapporten var resultatet af et udvalgsarbejde, der blev iværksat af kulturminister Brian Mikkelsen i 2008. Forud for dette var gået en politisk debat, der var forårsaget af et betydeligt antal lukninger af biblioteker efter kommu-

Jens Thorhauge, senior rådgiver

Thorhauge Consulting, jt@jensthorhauge.dk nalreformen i 2007. Fra 2006 til 2008 lukkedes der således 171 biblioteker. De fleste af disse lukninger fandt sted på fagligt initiativ. Det vil sige, at det var de kommunale bibliotekschefer selv, der fandt det hensigtsmæssigt at nedlægge filialer, der blev vurderet som mindre rentable, $i$ den forstand at udgifter til drift af bygning, samling og personale var uforholdsmæssigt højt i forhold til benyttelsen sammenlignet med f.eks. hovedbibliotekets. Mange bibliotekschefer fandt at kommunalreformen var en passende anledning til at stramme systemet op. Biblioteksstyrelsen forklarede så pædagogisk som muligt hvilke ræsonnementer, der lå bag den strukturreform, som reelt var i proces. Men i offentligheden og blandt politikere var der mange bekymrede røster, der så lukningerne som kulturtab. Og naturligvis var det et tab i de lokalsamfund, der mistede deres bibliotek, der ofte var det sidste fælles mødested. Men formålet med lukningerne var at effektivisere det samlede system. Debatten ledte til at kulturministeren blev kaldt i samråd for at gøre rede for, hvordan han ville hindre uønsket biblioteksdød i Danmark. Der blev gået hårdt til ministeren og selvom målet var at forklare de fleste lukninger som en rimelig rationalisering i kølvandet på strukturreformen, så måtte ministeren trække 'udvalgskortet' og love en rapport, der undersøgte, om der var brug for at etablere nye koncepter for en biblioteksbetjening, der imødekommer borgernes behov for oplysning uddannelse og kulturel aktivitet.

Udvalgets analyse baserede sig for omverdensanalysens vedkommende især på forskning i videns- og 
netværkssamfundet, som udviklet af forskere som Castells, Giddens, Baumann og Lyotard. Udvalget fokuserede på, at det ikke alene er medielandskab og medievaner, der forandres med digitaliseringen, men at det er kulturgrundlag og generelle livsvilkår, med hastigt tab af traditioner og vaner til følge. Forandringerne blev således betragtet både under en mere snæver biblioteks digitaliseringsvinkel og en bredere civilisations- og kulturforandring, der skaber nye behov og muligheder.

I meget kort form er udvalgets hovedanbefaling som konsekvens af disse forandringer skabelse af et nyt bibliotekskoncept, der udvikler digitale betjeningsformer og som samtidig fastholder og udvikler biblioteksrummet mod en større åbenhed på alle niveauer og et bredere spektrum af aktiviteter og tilbud.

\section{Udviklingsarbejde forud for Folkebibliotekerne $i$ vidensamfundet}

Det er også relevant for en forståelse af udviklingsprocessen, at udvalgsarbejdet om folkebibliotekerne i videnssamfundet ikke startede fra en analog position. Siden internettets gennembrud blev der i bibliotekssektoren arbejdet målrettet med forandringsprocesser. Dorte Skot-Hansens bog om det lokale bibliotek (Anderson \& Skot-Hansen, 1994) er et tidligt eksempel herpå ligesom en række rapporter og projekter initieret af Biblioteksstyrelsen.

Regeringens globaliseringsstrategi Fremgang, fornyelse og tryghed (Regeringen, 2006) hvor der blev opereret med 350 mål, der i vid udstrækning var adresseret uddannelse, læring og forskning i et nyt medielandskab, udkom 2006. Biblioteksstyrelsen lancerede samme år sin strategi Fra information til viden (Biblioteksstyrelsen, 2006), der var blevet præsenteret og diskuteret på møder rundt om i landet og på diverse årsmøder. Strategien havde 24 indsatser, hvoraf de fleste så at sige foregreb rapporten om bibliotekerne i vidensamfundet, eller mere præcist: rapportens analyser og anbefalinger lå i klar forlængelse af denne strategi og den tænkning, der blev præsenteret i rapporten Fremtidens biblioteksbetjening af børn (Biblioteksstyrelsen,2008). Denne rapport var et resultat af et andet udvalgsarbejde, der også var iværksat af Brian Mikkelsen, som en reaktion på det markant faldende benyttelsestal for børn i folkebibliotekerne. Der er meget klare linjer i de anbefalinger og mål, der arbejdes med her, som fører frem imod
Folkebibliotekerne $i$ vidensamfundet. Strategien har for det første klart fokus på netadgang til materialerne, 'sømløs arkitektur', som det hed, en fælles indgang til både digitale og fysiske materialer, en vision der blev arbejdet meget intenst med. For det andet er der en vision om en grundlæggende forandring af det fysiske biblioteksrum, hvilket er særlig interessant i denne sammenhæng. I Biblioteksårbogen 2006 (Biblioteksstyrelsen (2007) skriver jeg, at 'Det fysiske bibliotek skal forlade sin karakter af boglager og udvikle nye modeller for forundrings- oplevelses- og læringsrum'. Der er også en vision om, at de bibliotekariske kompetencer skal i spil, hvor folk er og ikke bare i det fysiske biblioteksrum. Rapporten om børnene havde fokus på at skabe nye aktiviteter og metoder til at fremme både traditionelle mål som læsefærdighed og nye mål om kreativ leg og nettjenester målrettet børn. Denne tænkning foldes ud for unge og voksne i Folkebibliotekerne $i$ vidensamfundet.

Det er også værd at nævne, at der var en intens lobbyvirksomhed fra Danmarks Biblioteksforening, der ønskede nedsættelse af en globaliserings- og vidensamfundskommission, der skulle udarbejde en strategi for Danmark som vidensamfund. Foreningen henviste bl.a. til Finland, hvor statsministeren havde sat sig selv som formand for en sådan kommission. Den resulterede bl.a. i en strategi for Finlands digitale bibliotek, der rigtig nok var langt mere ambitiøs og omfattende end de danske tiltag. Den politiske reaktion på foreningens forslag var, at det arbejde var i Danmark udført med den ovenfor omtalte regeringsrapport, Fremgang, fornyelse og tryghed, så det var åbenlyst, at der ikke ville blive nedsat en sådan kommission. Men man kan antage, at foreningens indsats har været medvirkende til at Kulturministeren under samrådet om bibliotekslukninger foreslog, at der blev iværksat et udvalgsarbejde. Hvor kommissionsprojektet ville være et stort tværministerielt arbejde, blev det af ministeren foreslåede udvalgsarbejde henlagt til Biblioteksstyrelsen og styrelsens direktør udpeget til at lede arbejdet.

Der skal ikke her redegøres for udvalgsarbejdet, undtagen hvad angår et enkelt aspekt ved firerumsmodellen. Hovedtænkningen i udvalget var, at vidensamfundet kalder på et nyt bibliotekskoncept, der er defineret af bibliotekets service og aktiviteter og mindre af samling og bibliotekets institutionelle karakter. Visionen var en større åbenhed på alle fronter, både $\mathrm{i}$ forhold til adgang til det fysiske og virtuelle 
bibliotek og i forhold til at skabe åbne lærings- og oplevelsesrum, brugerdrevne aktiviteter samt mere indbydende rum, hvor aktiviteterne i højere grad end tidligere tænktes skabt i mange nye partnerskaber.

Det var i udvalgsarbejdet, at idéen til en grafisk illustration af udvalgets tanker om nye rum opstod. Det skulle i give fald være en slags modeltegning. Et eksempel var den firerumsmodel, som Dorte SkotHansen udviklede i 90'erne under arbejdet med bogen 'Det lokale bibliotek - udvikling eller afvikling' (Anderson, Marianne og Dorte Skot-Hansen, 1994). Derfor bad udvalget Dorte om at prøve at arbejde med en tilsvarende model, bare baseret på det nye bibliotekskoncept, som var udvalgets arbejdsvision. Dorte valgte at udvikle modellen sammen med kollegerne på instituttet, Casper Hvenegaard Rasmussen og Henrik Jochumsen, hvor sidstnævnte i øvrigt var medlem af udvalget.

Den firerumsmodel, der kom ud af dette samarbejde, var efter min vurdering en stærkt medvirkende faktor til den meget positive modtagelse, som rapporten 'Folkebibliotekerne i vidensamfundet' fik i bibliotekerne.

\section{Modelprogrammets tilblivelse}

I foråret 2011 kontaktede jeg fonden RealDanias direktør, Hans Peter Svendler, som jeg år tidligere havde haft et samarbejde med. Jeg skrev ganske enkelt et brev til ham om de forandringer, der fandt sted på biblioteksområdet, som efter min opfattelse kaldte på nye arkitektoniske rammer, som er et af RealDanias arbejdsområder. Jeg beskrev især to tendenser. Den ene var udviklingen i benyttelsen af biblioteksrummet som lærings-, oplevelses- og mødested i stedet for det klassiske udlånsbibliotek, herunder bibliotekets potentiale som katalysator i en byudvikling. (Samme år blev denne udvikling smukt dokumenteret i 'Biblioteket i byudviklingen' skrevet af holdet bag firerumsmodellen). Den anden tendens var den overraskende hurtige vækst $\mathrm{i}$ åbne selvbetjente biblioteker. Det første forsøg med åbne biblioteker var i Gjern i Silkeborg Kommune. Udviklingspuljen støttede med stor interesse forsøget i 2006 som en øvelse, der foregreb det store antal bibliotekslukninger efter kommunalreformen. Biblioteket i Gjern var udset som et ud af fem små filialbiblioteker, der skulle overleve og så til gengæld boostes, bl.a. med en revolutionerende nytænkning af åbningstid og adgangsforhold. Jeg husker tydeligt min eksalterede begejstring, da jeg læste projektansøgningen om langtidsåbning, men jeg havde aldrig forestillet mig, at udviklingen ville gå så hurtigt, som den gjorde. Min opfattelse var, at vi dermed stod overfor en udfordring med at nytænke bibliotekets indretning, så rummet bedre faciliterede den selvhjulpne borger. Jeg foreslog et åbent samarbejde om projektudvikling.

Det gik også hurtigt med RealDanias reaktion på min henvendelse. Jeg blev ringet op af Hans Peter Svendler dagen efter, at jeg havde skrevet til ham. Han inviterede mig til et møde så hurtigt som muligt, fordi de udviklingstendenser, jeg havde beskrevet, lå helt i tråd med den kvalitative udvikling af arkitektur og byrum, som RealDania arbejder med. RealDania havde gode erfaringer med at udvikle modelprogrammer for seriebyggerier eller andre byggerier, hvor der arbejdes med faglige kravspecifikationer. Idéen i et modelprogram er at udføre et grundigt forarbejde som en bygherre kan trække på både ved nybyggeri og til- og ombygninger. Erfaringen var, at et modelprogram kunne medvirke til at højne kvaliteten af byggeriet ved at samle og dele bredt indhøstede erfaringer og overvejelser og dermed tjene som inspiration. Der var med held afprøvet modelprogrammer for folkeskoler, plejeboliger og hospicer.

Vi blev hurtigt enige om en skitse til et modelprogram projekt, hvor RealDania ville finansiere $50 \%$ af udgifterne, og Styrelsen for Bibliotek og Medier resten. Hovedidéen var at få et godt arkitektfirma til at medvirke til at udvikle programmet sammen med biblioteksfolk. Der blev nedsat en styregruppe med repræsentation fra RealDania, styrelsen, IVA og folkebibliotekerne.

Styregruppen hyrede Signal arkitekter som den arkitekturfaglige partner. Da jeg efter den første start pga. alder i 2012 ønskede at fratræde som direktør i den ny fusionerede Kulturstyrelse, havde jeg selv tænkt, at jeg gerne ville fortsætte arbejdet i styregruppen og afslutte arbejdet med modelprogrammet. Men den nye direktør ønskede at overtage formandsposten. I stedet blev jeg sammen med Dorte faglig konsulent på projektet, hvor vi bl.a. tilrettelagde og deltog $\mathrm{i}$ de studiebesøg styregruppen foretog $\mathrm{i}$ indog udland og skrev de første cases. De skulle lægges op på den dynamiske hjemmeside, vi var enige om skulle være projektets 'rapport'. 
I udgangspunktet var styregruppen af den opfattelse, at tænkningen i Folkebibliotekerne $i$ vidensamfundet og firerumsmodellen skulle lægges til grund for programmet. Det var Signal enige i, principielt. Men de fandt, at det ville være at foretrække kun at arbejde med to 'rum'. I de indledende faser af arbejdet kom der forskellige forslag, som de biblioteksfaglige medlemmer af udvalget imidlertid skød ned, fordi de ikke dækkede den tænkning, der ligger bag firerumsmodellen. Så til slut blev modellen valgt som grundstruktur for modelprogrammet.

Der var også en idé om, at der skulle udføres et desk-study, der f.eks. kunne resultere i en annoteret bibliografi om folkebiblioteksarkitektur og ny biblioteksstrategi. Dorte og jeg blev sat til at udføre denne opgave. Vi gik en ret omfattende litteraturmængde igennem og udarbejdede en annoteret bibliografi, der omfattede omkring 40 titler på nordiske sprog og engelsk. Dette arbejde blev imidlertid skrottet af Signal arkitekter, da det efter deres mening var alt for omfattende. De ville gerne have en note med de fire-fem vigtigste titler. Det fandt vi for reducerende, så vores desk-study blev ikke bragt i spil.

\section{Et nyt paradigme}

I dag vil jeg rejse det spørgsmål om vores desk-study, om der var vigtige tendenser i det materiale, vi gennemgik, som vi overså? Eller om vi burde have konkluderet tydeligere? Materialet var for de fleste titlers vedkommende mindre end fem år gamle og kun enkelte udgivelser fra før 2005. På det tidspunkt hvor vi udførte opgaven, forekom det mig, at der kun var spæde gennemgående tendenser. Det vi fandt var oplagt. Det relaterede sig til en fælles forståelse af, at digitalisering og globalisering har dybtgående effekt i forhold til opløsning af traditioner og ændring af arbejdsprocesser og kulturforbrug. Og naturligvis at skiftet fra analog til digital platform ændrer de fleste arbejdsprocesser. At biblioteket var på vej med nye roller og funktioner, men ikke klarhed om hvilke. Men spørgsmålet om, hvad man finder, er jo i høj grad bestemt af, hvad man ser efter. Omkring tidspunktet for internettets gennembrud talte vi i biblioteksverdenen meget om 'paradigmeskifte'. Begrebet paradigmeskifte blev brugt som en bred, ret upræcis betegnelse for dybtgående forandringer. Bag begrebet var oplevelsen af grundlæggende ændring af informationssøgningens rolle og karakter. Af referencesamlingens hensygnen men også af de muligheder for udnyttelse af digitale medier, som universitetsbibliotekerne allerede kunne demonstrere i Danmarks Elektroniske Forskningsbibliotek (DEF), der gjorde, at paradigme-begrebet blev bragt i spil. I bakspejlet kan jeg se, at jeg blev forført af billedet: et paradigmeskifte tænkt som en udskiftning af ét paradigme med et andet fik mig til at lede efter det nye paradigme, bestående af et sammenhængende sæt af tanker og begreber, der tydeligt erstattede det gamle paradigme. Men det kunne jeg ikke få øje på.

I det analoge bibliotek var der et klart paradigme, som man kan kalde 'access to information'-paradigmet. Formålet og alle bestræbelser var grundlæggende baseret på, at give borgerne adgang til information, forstået bredest muligt, herunder selvfølgelig også kulturel aktivitet. Paradigmet var baseret på ensartede og kompatible systemer og standarder. Der kunne i vid udstrækning arbejdes med 'best practice' for opbygning, dimensionering og vedligeholdelse af bibliotekssamlingen. Kronen på værket var UAP programmet (Universal Availability of Publications Core Activity var et IFLA program der opererede fra 1979 til 2003), der i den analoge verden nåede næsten fuldkommenhed: alle publicerede værker i verden var i princippet tilgængelige for alle gennem interurbanslånsaftaler og -systemer. Med den digitale revolution og de digitale medier og dermed en ny kompleks ophavsretslig situation i bibliotekerne drejede fokus hurtigt væk fra denne opgave. I første omgang til fordel for et arbejde med i det mindste at give adgang til nogle af digitale medier og med at udnytte teknologien til nye formidlingsformer, herunder introduktion af internettet og den nye teknologi. Men et koncept der kunne fungere som et fælles paradigme blev ikke udviklet.

\section{Det kasserede desk-study}

Problemstillingen kan eksemplificeres af nogle punktnedslag i den bibliografi, Dorte og jeg udarbejdede, på hver for sig centrale fremtidsstudier for folkebiblioteker. Brian Edwards (2009) diskuterer i Libraries and Learning Resource Centres bl.a. folkebibliotekernes udvikling ud fra tre tendenser, 'high tech access to learning', 'community focus' og 'cultural tourism'. De to første tendenser passer fint, mens den tredje forekommer perifer set fra en dansk sammenhæng. Men Edwards er i øvrigt tæt på den danske forståelse, fordi han uden at gå ret langt ind i konkrete eksempler fastholder, at bibliotekerne er 
i færd med at udvikle nye roller i takt med den postmoderne udvikling. De vil være hinsides institutionens funktionelle oprindelse og have mennesker og ikke bøger i centrum, men mere konkret bliver han ikke.

Den samme problemstilling genfinder man i den hollandske rapport The future and the Dutch public library ten years on fra 2008 (Huysmans, \& Hillebrink, 2008). Rapporten er gennemført af det hollandske Socialforskningsinstitut og fokuserer på bibliotekets sociale funktion og kerneopgaver i samspil med demografiske og sociokulturelle forandringer og ændringer i medielandskab og -benyttelse - og fremskriver så som et estimat udviklingen med ti år. Konklusionen er, at enten visner biblioteket væk, eller også må det løse oplysningsopgaver anderledes. Men når det kommer til det mere konkrete, bliver rapporten forsigtig. Den peger på at udvikle nye digitale services, en højere grad af 'customised service', et skifte fra samlingsorientering til konsultation og samtale. Men en samlende forståelse af hvordan biblioteket skal udvikle sig leder man også her forgæves efter.

Et tredje eksempel er Confronting the Future: Strategic Visions for the 21st Century Public Library (Levien, Roger E., 2011). der er udgivet af den amerikanske biblioteksforening, ALA. Bogen opstiller ikke en endelig strategi, men opererer med fire dimensioner, som det enkelte bibliotek må afklare sin position på i valg af fremtidsstrategi: I hvilket omfang satser biblioteket virtuelt og i hvilket fysisk? Er det det lokale samfund, der er i fokus eller den enkelte borger i valg af services, er det samlingen eller kreativ udvikling, der er i fokus, ser biblioteket sig selv som arkiv for materialer eller i højere grad som portal? I denne bog er der således heller ikke det paradigmebud, som jeg ledte efter, men indirekte har den svar, som jeg ikke greb i første omgang: der er ikke et samlet paradigme, der er en række valg, som det enkelte bibliotek kan og må gøre. Og det kan og vil være forskelligt fra bibliotek til bibliotek.

Det var senere rapporter fra ALA, der for alvor gav mig forståelsen for, at biblioteker for den del af deres virksomhed, der ligger udover den grundlæggende fælles infrastuktur, fra grunden må udvikle hver sin strategi, og at biblioteker fremover vil adskille sig langt mere fra hinanden end tidligere. Det er rapporter som Reinventing the library for online Educa- tion (Stielow, 2015), Planning our Future libraries: Blueprints for 2025 (Leeder \& Frierson, 2014) og Reflecting on the Future of Academic and Public Libraries (Hernon \& Matthews, 2013). I den sidste er der en anbefaling af at arbejde med scenarier. Man kan arbejde f.eks. med 'status quo biblioteket' (anbefales ikke), med ' det elektroniske bibliotek', 'lokalsamfundets dagligstue' eller med 'biblioteket som kulturel arena'. Bogen anbefaler at kombinere dette scenariearbejde med mere traditionel amerikansk planlægning efter de fire p'er: products, people, places, programs.

Det er her, vi finder konturerne af det nye paradigme, der peger mod en virksomhed, der i sin dynamiske fleksible og brugerorienterede form er hinsides industrialismens bureaukratiske institutionsforståelse. Der findes ikke ét facit, ikke ét koncept, der er det rigtige. Der findes lokale og individuelle løsninger, der naturligvis ligger inden for bibliotekslovens formålsparagraf, men som alle må bygge på forskelige lokale behov og muligheder. Hvilke partnere, hvilke andre politikker, hvilke ressourcer, hvilke kompetencer, der findes lokalt, vil afgøre virksomhedens karakter.

\section{Hvorfor blev modelprogrammet en succes?}

Modelprogrammet blev en succes, fordi det opfyldte et behov. Behovet for det nye paradigme. Modelprogrammet har med sine funktions- og formålsbeskrivelser en karakter, så det kan gøre det ud for et paradigme. Samtidig er dets modelkarakter så klar, at det ikke låser forståelsen, men er fleksibelt og dynamisk. Først og fremmest beskriver det et bibliotekskoncept, hvor adgang til en samling af fysiske materialer og til (nogle) digitale medier er delydelser i en virksomhed, der går længere ind i processerne med at aktivere og inddrage borgerne, hvad enten det er læring, kulturel oplevelse eller aktiv skaben end tilfældet er med det klassiske bibliotek. Helt enkelt skifter paradigmet fra at biblioteket er et sted, der stiller materialerne til rådighed til et sted, hvor man som bruger i højere grad får mulighed for at gøre noget aktivt, deltage i noget, opholde sig. Den konkrete realisering af konceptet skifter fra sted til sted afhængig af lokale behov, partnere, kompetencer og ressourcer. Klare indikatorer på denne udvikling er væksten i læringstilbud og arrangementer i folkebibliotekerne, der kan aflæses i det årlige Biblioteksbarometer. 
På Bibliotekschefforeningens årsmøde i 2015 var jeg inviteret til at komme med et bud på fremtidens strategiske udfordringer for folkebiblioteket, ud fra en forestilling om, at det strategiske tankegods i 'Folkebiblioteket i vidensamfundet' var slidt op. Jeg ser tre fundamentale opgaver:

- At dimensionere de klassiske biblioteksydelser og skabe rum nok til at nå nye brugergrupper, nye oplysningsbehov, udvikle nye ydelser

- At synliggøre, udnytte og integrere den strøm af digitale tilbud der skal komme, bl.a. fra Danskernes Digitale Bibliotek

- At skabe en fleksibel organisation og arbejdskultur der kan skabe en ny slags institution, der understøtter et nyt dannelsesbegreb med læring og inspiration, skaben og deltagelse - også uden for det fysiske biblioteksrum

Men modelprogrammet kan forsat fungere som en ramme for tænkningen i det enkelte bibliotek, når det udvikler sin egen strategi og foretager sine egne prioriteringer og valg. Jeg ser modelprogrammet og den måde det drives på som en ideel ramme for den strategiopgave, som hvert eneste bibliotek må løse. For strategiopgaven løses jo ikke i et tomrum. Firerumsmodellen kan et stykke tid endnu fungere som en paradigmatisk ramme, der kan moduleres, modificeres og udbygges efter de lokale brikker.

\section{Referencer}

Anderson, M \& Skot-Hansen, D (1994). Det lokale bibliotek - afvikling eller udvikling. København: Danmarks Biblioteksskole og Udviklingscenter for folkeoplysning og voksenundervisning.

Biblioteksstyrelsen (2006). Fra information til viden. Tilgængelig online på http://www.bs.dk/publikationer/rapporter/strategi/index.htm
Biblioteksstyrelsen (2007). Biblioteksårbog 2006. København: Biblioteksstyrelsen.

Biblioteksstyrelsen (2008). Fremtidens biblioteksbetjening af børn. København: Biblioteksstyrelsen.

Edwards, B (2009). Libraries and Learning Resource Centres. Amsterdam: Elsevier.

Hernon, P \& Matthews, JR (eds) (2013). Reflecting on the Future of Academic and Public Libraries. Chicago: ALA.

Huysmans, F \& Hillebrink, C (2008). The Future of the Dutch public library ten years on. The Hague: Netherlands Institute for Social Research.

Leeder, K \& Frierson, E (eds) (2014). Planning our Future libraries. Blueprints for 2025. Chicago: ALA.

Levien, RE (2011). Confronting the Future: Strategic Visions for the 21st Century Public Library. Chicago: ALA.

Regeringen (2006). Fremgang Fornyelse og Tryghed. Tilgængelig online på http://www.stm.dk/multimedia/Fremgang_fornyelse_og_tryghed.pdf

Stielow, F (2015). Reinventing the library for online Education (2015) Chicago: ALA.

Styrelsen for Bibliotek og Medier (2010). Folkebibliotekerne $i$ vidensamfundet. København: Styrelsen for Bibliotek og Medier. 